\title{
MILITARY PREPAREDNESS A PERIL TO DEMOCRACY
}

\author{
By Charles E. Jefferson, D.D., LL.D., \\ New York.
}

An anti-preparedness man is always constrained to begin his argument with the declaration that he is a stout defender of the virtue of preparedness. In his opinion, so called anti-preparedness men are the most enthusiastic, consistent, persistent, and thoroughgoing preparedness people now alive. We place extraordinary emphasis on the absolute necessity of this nation preparing itself to meet coming duties and perils. We all believe in national defense. We all realize the value of security. We all desire to safeguard the nation against invasion. We are second to nobody in devotion to the flag, in desire to keep its folds free from stain, and to maintain the principles for which it was unfurled, and to preserve and perpetuate the institutions over which it waves.

The much derided anti-preparedness men freely admit that we as a nation are not prepared to meet victoriously the strains and storms of the coming years. We know that as a people we are not equipped to fulfill our obligations either to ourselves or to mankind. We realize we are not politically prepared. Our governmental machinery in its present shape is not adequate for our expanding needs. Our legal apparatus is not sufficiently developed to grapple with the world's baffling problems. We have not yet devised a way by which our national government can safeguard the lives of aliens in the various commonwealths. We have not worked out a plan by which a state on the sea coast can be prevented from nullifying a national treaty. We have no consistent and clearly stated policy in regard to immigration, or the tariff, or the Philippines, or the Monroe Doctrine. We have as yet created no commissions to work out in conjunction with the various nations involved, any of a half dozen intricate and irritating problems out of any one of which international conflict might arise. We have a department of the Navy, but no department of International Conciliation, a secretary of war but no secretary of peace. We spend the enormous sum of one quarter of a billion dollars every year on our army and navy, 228 
and scarcely a dollar for the maintenance of agencies for feeding the fountains of international goodwill. We have erected no safeguards by which a President of the United States can be prevented from plunging us into war. Technically only Congress can declare war, but as our constitution now stands, any President is at liberty in his dealing with foreign governments, to take steps of such a character that Congress is virtually committed to war. To reduce the points of international friction, and to work out a solution for the problems that hang on from year to year and which, because of their confused condition, are thunder clouds out of which lightnings may come: to foster and multiply the forces working for friendly feeling, and to create more effective legal devices by which the nations may live harmoniously together, this is preparedness of the most fundamental and indispensable sort, and of it we have altogether too little. The first charge which we bring against the labelled advocates of preparedness is that they overlook the things which are of primary importance, and lead the nation astray by creating a great hubbub over matters that are superficial, and do not at all touch the heart of the world problem.

There is such a thing as industrial preparedness, and we need it. The great world of the wage-earning masses must be elevated and harmonized, and a better spirit must be created in the hearts both of capital and labor. The idea that a nation's life depends wholly on the courage of its soldiers is an ancient superstition which the present war has exploded. The delusion that generals and admirals are the sole custodians of a nation's honor has been dissipated forever. We now know that mechanics are as necessary for success on the battle field as the men who carry guns, and that without the loyal support of the common day laborer no nation can hope for victory. When Mr. Lloyd George begged the Welsh coal miners to go back to their work, assuring them that the destiny of the British Empire rested on their shoulders, the world caught a glimpse of a fact it will never forget. No nation can any longer be victorious in war unless it has the loyal coöperation of all classes of its people. Unity of spirit, even more than dreadnaughts and howitzers, is the final safeguard of a nation's life. The men who give their days and nights to elaborating fresh schemes for the multiplication of guns, deal too much with the physical, forgetting that at last everything depends on a nation's soul. 
There is such a thing as social preparedness, and we ought to think about it. We are an unkempt and undisciplined people. Things run at loose ends in every department of our life. We are extravagant and wasteful beyond belief. We lack social efficiency. Many of our municipal governments are a scandal. Our administration of public affairs is often a disgrace. We are not fitted to play our part creditably in the family of nations. What we most need is certainly not a club.

And are we as a nation morally prepared? Read the annual record of our homicides, our divorces, our drunkenness, and our thefts and robberies and defalcations, and all the atrocities of high finance, and you must admit that we are not morally prepared to face triumphantly the searching fires of the coming years. Our criticism of the so-called preparedness crowd is that they think too much of the outside of the cup and the platter and forget to look inside. They think only of the external armor, and pay scant attention to the interior defenses, lacking which a nation inevitably succumbs. Physical armor saves no nation. All the perished nations of history went down to death with their armor on. The enemies which America has most to fear are not conjectural foes four or five thousand miles away. Our deadliest enemies are inside our own gates. O you Americans who clamor so loud for preparedness, why do you not get your eye on the foes which are foes indeed?

The world-tragedy of the last forty years has been the squandering of brain energy on devising material defenses which in the crucial hour failed to save Europe from the unspeakable havoc which they had been created to ward off. If one tenth of the money spent on defense had been spent in cultivating kindlier feelings and loftier ideals, this war would never have been. The tragedy of the Hague Conferences was that both in 1899 and in 1907, a large part of the time was devoted, not to working out a scheme by which war might be abolished, but to the work of laying down technical rules by which the bloody game of human butchery could still be played. This is the tragedy of America at the present hour. When every sound mind and heart should be brooding over the question: How can we so order the world's life that a recurrence of this tragedy shall never be, there are thousands of Americans thinking of nothing else, talking of nothing else, suggesting nothing else but the old stupid experiment which has again and again soaked our planet 
with blood. How are we ever going to get out of the heart-breaking predicament in which humanity finds itself unless men who think, dare to break away from the military traditions which have cursed and destroyed so many generations? Cannot we get beyond the ideas of Tiglath Pileser and Ramses II? Can not we rise above the ideal of the cave man? He always armed for defense. He thought only of his own skin. He was a low-down undeveloped creature, and is to be excused, because he lived in the morning of the world. But what shall we say of men who, living two thousand years after the death of Jesus Christ, cannot advance an inch in their conception of international life beyond that which was regnant in the ancient barbaric world?

But some one asks: Do you not believe in any army or navy at all? Certainly. We all believe in an army and navy for police purposes. That is not now up for discussion. The question before the American people is shall we have adequate preparedness-that is, a preparedness which is considered adequate by the military-naval experts? That is a kind which we have never had. From the days of Washington we have been continuously unprepared. All the experts say so. For one hundred and forty years we have lived in a fool's paradise. The specialists are all agreed. We now spend 250 million dollars a year, but this is a mere bagatelle. "This is not preparedness at all. Let us now prepare in earnest!" But a multitude of us shout no! Not now. Not till the end of the war at least. Let us lick into shape the army and navy we already have. Let us learn how to spend a budget of 250 millions before we squander more.

But somebody says: Is there not danger of a foreign invasion? We think not. No such danger has ever existed, and there is less danger now than at any time in our whole history. Our greatest peril is the peril of military preparedness.

Military preparedness is a peril to democracy, and a menace to the peace of the world. Piling up explosives in a world where so many persons carry matches is perilous. Running races in naval tonnage is exciting, but perilous. Diplomacy which relies on the pressure of guns is sometimes effective, but always perilous. Making other nations afraid of us is perilous. Germany made her neighbors afraid of her, and so she was gradually surrounded by a tightening ring of steel. We shall circle ourselves with a similar 
ring by a like policy of military efficiency. It is perilous to drill the young men of a nation in the art of shooting human beings. It brings a degradation of the spirit which is blighting. It is perilous in these restless days, to pile additional burdens on the backs of the taxpayers for the support of vast numbers of men in barracks and on battleships. It is perilous to squander on instruments of slaughter the money entrusted to us by the Almighty for the service of mankind. Our nation is a steward, and it must render a strict account for all its gold. This is a fact which political and social science must never fail to take into account. As Huxley used to say: "We are playing a game with a player who makes no mistakes." It is perilous to waste the time of our National Congress in interminable discussions over the army and navy. For twenty-five years Congress has shamefully neglected matters of sovereign importance to devote session after session to wrangling over the types and numbers and prices of ships and guns. It is perilous to play with the passion of fear. Fear is the mightiest and most demoralizing of all the passions. Fear paralyzes the nerves of reason. Men no longer think when they are afraid. Militarism flourishes only in an atmosphere of fear. Huge appropriations for ships and guns are possible only when nations are terrorized. The astute men who are at the bottom of all this preparedness movement know that now when the whole world is panic stricken because of long continued bloodshed, is the best possible time for making a desperate effort to swing our republic still farther out into the maelstrom of military preparedness.

Building a huge war machine is perilous again because it plays into the hands of five men who because of the structure of modern civilization are endowed with extraordinary power for working mischief. First comes the military-naval expert. Modern armies and navies are colossal. Officers are numbered by the thousands, 35,000 to every million men. Some of these officers are certain to be Homer Leas and Bernhardis. This is inevitable. You cannot have a gigantic war machine without a military caste. You cannot have a military caste without a war party. You cannot in this republic prevent army and naval officials of a certain type chattering with reporters, talking at banquets, writing for magazines and the Sunday newspapers, publishing books, everlastingly trying to 
scare the public, and working day and night to increase the size and prestige of the military and naval establishments.

Along with the military naval expert comes the war trader. Vote hundreds of millions of dollars for any purpose whatever, and you raise up at once colossal corporations eager to make the profit which vast contracts bring. Wherever you have great armies and navies, you have the Krupps, and the Armstrongs , and the Vickers, and the Creusots, and in order to keep their costly machinery running, you must always, even in days of profoundest peace, be vigorously preparing for war. You must change your guns every few years, you must scrap heap your ships before they are used and buy new ones. The nations are systematically and continuously and mercilessly fleeced.

Next comes the irresponsible newspaper editor. He fears neither God nor man. He fills his columns day after day with insolent gossip and lying rumors, always poisoning the wells of international good will, always playing on the fears and the prejudices and ignorance of the crowd. Some future Dante who writes the Divine Comedy of America will put this type of scoundrel in the lowest round of hell.

And then comes the Jingo politician, the glowing, effervescing patriot who wants the United States flag to float all the way to the Isthmus, or who is certain that in a hundred years we as a nation will be extinct, or hold in our possession the entire North American continent. Who has power to close the mouths of the dunces? By every increase in your army and navy you add new cubits to the stature of every fool in the land.

And finally there is the commercial exploiter, the money maker who rushes into belated countries and gathers up concessions, and stakes out zones of influence. He invests the millions of powerful corporations and syndicates. By unscrupulous methods he pushes his operations, counting on the government to safeguard his investments by its army and navy. The gold of a few men shall be made safe by the blood of the boys of other men. He is a dangerous man. In every war of the last twenty-five years, he has been at the center of the clique which has brought on the conflict. The bigger the army and navy, the more insolent and ambitious this arch-mischief maker becomes.

The military and naval expert of the Bernhardi type, the covet- 
ous and unscrupulous war trader, the irresponsible and diabolical newspaper editor, the hot-headed Jingo politician, and the pushing and rapacious commercial promoter-look at them! These are the five fingers of the hand which is now crushing the world. You cannot increase the size of your war machine without increasing the strength of every one of these fingers. To break the power of that infernal hand, is the first and most imperative duty of all men who love mankind.

Sombody says: "We arm solely for defense. We prepare not for war, but against war." Indeed! European nations prepared only against war, and behold! You cannot change a situation by altering a preposition. Things are what they are, no matter what names you give them. Preparing against war is identically the same thing as preparing for war, and that is why all the military naval experts, and all the war traders, and all the editors of the baser sort are heartily in favor of it. They like the change of the preposition. It hoodwinks innocent people who do not take time to think the subject through.

"We are never going to use our army or our navy for aggression." Who said that? Who has authority to say that? No one. The Secretary of the Navy cannot say it. Poor man, he will be out of office long before the big machine he has planned is ready for use. No congressman can say it. He also is like a flower of the field. In the morning he grows up and flourishes, but in the evening he is cut down and withered. No President of the United States can say it. He is in his office for a brief season, and then the place that once knew him knows him no more. He may possibly be succeeded by a megalomaniac who has a fashion of thinking his own notions synonymous with eternal justice, and who when he wants a thing takes it. Let no one be fooled by all this talk about never using our army and navy except for defense. Create a war machine, and God only knows who will use it!

"Ah, but we are a peace loving people." So we are, and so are all Europeans. There is not a war loving people in Europe. They all love peace. They all hate war. They spent forty billion dollars in trying to ward this war off. They simply prepared for it, and so they got it. We live in a universe in which we get not what we want, but what we deserve. Our deserts are determined by our actions. Whatsoever we sow, we reap. The universe pays no at- 
tention to what we want. No tipler or guzzler wants delirium tremens. He simply wants the exhilaration which alcohol imparts. But let him drink long and hard enough and delirium tremens comes. We do not want war, but let us make ever increasing preparation for war, and there is no escape. Whatsoever we sow we reap: what we prepare for we get. This is the solemn significance of preparedness, it leads to death! Therefore let us prepare now for peace. It will take the self sacrificing labors of tens of thousands of men, we know not how many years, to work out the machinery of peace. We have got to organize the world. It will cost brain and time and money. Let us spend money for peace, tens of millions, hundreds of millions, billions, tens of billions, whatever is necessary for peace!

The preparedness program of the administration makes me sick at heart. Either America is likely to be invaded or she is not. If she is in danger of invasion, this program is a trifling and paltry thing, nothing but a sop to the militaristic Cerberus. It is simply playing with fire. If we are not likely to be invaded, then this program is wildly and wickedly wasteful. It would be wicked at any time, but is a hundredfold more wicked just now, when we stand at the gravest crisis in all human history, and when every nation not engaged in the conflict ought to be asking itself, not how it can save its own hide, but how it can minister to the crying and awful needs of a wounded, bleeding world. Tens of thousands of human beings like ourselves-men, women and little children-are on the verge of starvation, and our government officials come forward with a scheme that calls for the expenditure in one department alone of 500 million dollars within five short years for the extension of the machinery of human slaughter. Not one dollar for bread-but every dollar for the dogs of war! " $O$ judgment, thou hast fled to brutish beasts, and men have lost their reason." Would that we had a secretary of peace, a man who, at an hour like this, would present a scheme for increasing the happiness and well being of our people. Millions for new roads, millions for new buildings, millions for new schools, millions for new farms to be carved out of the deserts and the swamps, millions for fighting disease, millions for preventing accidents, millions for brightening the lives of the poor and the ignorant and the forlorn, millions for the solution of problems which have long vexed us, and millions for forwarding noble enterprises to 
their coronation. Five hundred million dollars to be spent the next five years in making us a healthier, happier and better people. This is the preparedness which fits us to fulfill our duties. This is the preparedness which fits us to stand before God!

But this would not defend us - some one says - from our foreign enemies. They would be attracted by our increased prosperity and might break in and steal our trcasures. Well then, let us build up lines of defense in foreign lands. We have spent one hundred and seventy eight million on coast defenses, and an expert has declared that any foreign army can easily walk around them. Why not build coast defenses which nobody can walk around? Why not build them in the hearts of the nittions? $O$ for a sccretary who would suggest not 500 million dollars for machincry to sink boys of foreign countries to the bottom of the sea, but who would recommend 500 million dollars for healing the open sore of the world. The price of a dreadnaught to each of the warring nations for the erection, at the close of the war, of asylums and hospitals and orphanages and homes and schools for the service of the great company of those whom the war will have left impoverished and helpless. The price of a battle cruiser and torpedo boat and a submarine to each of those nations for the endowment of these various institutions. Five hundred million dollars for the relief of the nations who are stripped of their raiment, and wounded and half dead. Why should it be thought a thing incredible that a Christian nation should do a Christian deed? Would there then be danger of a foreign invasion? Some men are so hidebound in their materialism they cannot conceive of any defenses except those made of concrete and steel. We Americans are often accused of worshiping the almighty dollar. We are counted money makers, money grabbers. Why not show the world that we can be money givers? Why not cease this shameful shivering and whimpering over the prospect of somebody hurting us, and show the world that we can think of helping others? Spend your 500 millions on war ships, and in less than twenty years they are all on the scrap heap. Spend 500 millions on institutions scattered over Europe for the care of those whom this awful war has maimed and mangled, and they will stand forever as the imperishable monuments of a great republic's love. Do you say this is impracticable? I tell you it is not. A noble deed is always practicable. 